Oxygen Tension.-We were unable to confirm the recent suggestion (Katz et al., 1971) that "oxygen transport" may be limited in subjects who develop exercise-induced bronchoconstriction. Though there was a higher arterial $\mathrm{Po}_{2}$ during bicycle exercise in four patients, the mean arterial oxygen saturation did not fall below $96 \%$ in either study. In Case 1, in which oxygen saturation fell to $93.3 \%$ during treadmill exercise, the PEFR had also fallen (from 550 to $4051 . / \mathrm{min}$ ) during the last two minutes of exercise. In the other patients, whose PEFR did not fall during exercise, the small differences in arterial $\mathrm{Po}_{2}$ may be explained by relative hyperventilation during bicycle exercise, as discussed earlier. Arterial hypoxaemia, which has been reported after exercise in patients who develop exercise-induced bronchoconstriction, is likely to be the result of bronchoconstriction rather than its cause (Rebuck and Read, 1968).

\section{Conclusion}

As a result of the present study we are unable to propose any single factor which is responsible for the difference in exercise-induced bronchoconstriction after treadmill and bicycle exercise. We must speculate, as before (Anderson et al., 1971), that neuromuscular effects arising from the mechanical difference between the two forms of exercise may be responsible for the difference in exercise-induced broncho- constriction, either alone or in combination with other variables.

We are grateful to Dr. Margaret Turner-Warwick; the patients in this study were under her care. M.S. and S.D.A. were supported financially by Fisons Pharmaceuticals Limited.

\section{References}

Anderson, S. D., Connolly, N., and Godfrey, S. (1971). Thorax, 26, 396 Anderson, S. D., McEvoy, J. D. S., and Bianco, S. (1972). American Review

of Respiratory Diseases. In press.
Ferguson, A., Addington, W. W., and Gaensler, E. A. (1969). Annals of Internal Medicine, 71, 1063.

Fisher, H. K., Holton, P., Buxton, R. St. J., and Nadel, J. A. (1970). American Review of Respiratory Diseases, 101, 885

Hansen, J. E., Stelter, G. P., and Vogel, J. A. (1967). Fournal of Applied Physiology, 23, 523 .

Hermanson, L., and Saltin, B. (1969). Fournal of Afplied Physiology, 26, 31. Herxheimer, H. (1946). Lancet, $1,83$.

Irnell, L., and Swartling, S. (1966). Scandinavian fournal of Respiratory

Diseases, 47, 103.
Katz, R. M., Whipp, B. J., Heimlich, E. M., and Wasserman, K. (1971). fournal of Allergy, $47,148$.

Newhouse, M. T., Becklake, M. R., Macklem, P. T., and McGregor, M. (1964). Fournal of Applied Physiology, 19, 745.

Rebuck, A. S., and Read, J. (1968). Lancet, 2, 429.

Scadding, J. G., (1966). Lancet, 1, 701.

Seaton, A., Davies, G., Gaziano, D., and Hughes, R. O. (1969). British Medical fournal, 3, 556.

Stanescu, D. S., and Teculescu, D. B. (1970). Respiration, 27, 377.

Sterling, G. M. (1968). Clinical Science, 34, 277

Wasserman, K., Van Kessel, A. L., and Burton, G. (1967). Fournal of Applied Physiology, 22, 71.

\title{
Hypergastrinaemia in Chronic Renal Failure
}

\author{
M. G. KORMAN, M. C. LAVER, J. HANSKY
}

British Medical fournal, 1972, 1, 209-210

\section{Material and Methods}

Fasting serum was obtained from 89 patients with various types of renal disease. The degree of impairment of renal function was arbitrarily classified in relation to the serum creatinine-namely, normal function (serum creatinine $<1 \cdot 2$ $\mathrm{mg} / 100 \mathrm{ml})$, mild impairment $(1 \cdot 2-3.0 \mathrm{mg} / 100 \mathrm{ml})$, and severe impairment $(>3.0 \mathrm{mg} / 100 \mathrm{ml})$. The distribution of the underlying renal disease and the mean age of patients in relation to impairment of renal function is shown in Table $I$.

TABLE I-Distribution of Type of Renal Disease and Mean Age in Relationship to Serum Creatinine Level in 89 Patients

\begin{tabular}{|c|c|c|c|}
\hline & \multicolumn{3}{|c|}{ Serum Creatinine $(\mathrm{mg} / 100 \mathrm{ml})$} \\
\hline & $<1.2$ & $1 \cdot 2-3 \cdot 0$ & $>3.0$ \\
\hline $\begin{array}{lll}\text { Glomerulonephritis } & \ldots & \ldots \\
\text { Renal allografts } & \ldots & \\
\text { Other renal diseases } \\
\text { Age in years (mean } \pm \text { S.D.)... }\end{array}$ & $\begin{array}{l}17 \\
12 \\
0 \\
31 \pm 12 \cdot 6\end{array}$ & $\begin{array}{l}14 \\
19 \\
1 \\
33 \pm 13 \cdot 5\end{array}$ & $\begin{array}{r}16 \\
2 \\
8 \\
35 \pm 12 \cdot 1\end{array}$ \\
\hline
\end{tabular}

Eight patients (mean age 36 years) on chronic maintenance haemodialysis were also studied and fasting serum gastrin levels were compared before and after a 14-hour Kiil haemodialysis.

Serum creatinine, urea, and calcium were determined by standard methods and serum gastrin was measured by radioimmunoassay (Hansky and Cain, 1969; Hansky et al., 1971). The normal range is $0-120 \mathrm{pg} / \mathrm{ml}$.

Basal gastric acid secretion was measured by using the method of Kay (1953).

Statistical comparison of groups was by "Student's" $t$ test, and a $\chi^{2}$ was constructed to compare normal and abnormal

Melbourne University Department of Medicine, Royal Melbourne Hospital, Melbourne, Australia

M. C. LAVER, M.R.A.C.P., Fellow in Renal Medicine 
gastrin levels in the severely impaired and less severely impaired groups (Snedecor and Cochran, 1968).

\section{Results}

\section{NON-DIALYSIS PATIENTS}

The mean serum gastrin levels \pm S.E. of the mean in the three groups of patients with differing levels of renal function are shown in Table II. The difference between patients with

TABLE II-Relation of Basal Serum Gastrin Level to Serum Creatinine Level in Patients with Renal Failure

\begin{tabular}{|c|c|c|c|}
\hline & \multicolumn{3}{|c|}{ Serum Creatinine $(\mathrm{mg} / 100 \mathrm{ml})$} \\
\hline & $<1.2$ & $1 \cdot 2-3 \cdot 0$ & $>3.0$ \\
\hline $\begin{array}{l}\text { No. of patients } \\
\text { Serum gastrin in } \mathrm{pg} / \mathrm{mi}^{*} \text { (mean } \\
\pm \text { S.E. of mean) } \ldots\end{array}$ & $\begin{array}{l}29 \\
38 \pm 8 \cdot 9\end{array}$ & $\begin{array}{l}34 \\
51 \pm 9 \cdot 1\end{array}$ & $\begin{array}{l}26 \\
220 \pm 79 \cdot 6\end{array}$ \\
\hline
\end{tabular}

- Normal range 0-120 pg/ml.

severe renal impairment and patients with normal function or mild impairment is significant at $\mathrm{P}<0.025$. There was no significant difference in serum gastrin levels when patients were compared on the basis of underlying renal disease.

Two patients with severely impaired renal function had very high gastrin levels $(>1,500 \mathrm{pg} / \mathrm{ml})$ and may have unduly biased the mean values. A $\chi^{2}$ was therefore constructed and is shown in Table III. There was a strong association between

TABLE III-Relation of Degree of Renal Impairment to Serum Gastrin Levels in 89 Patients

\begin{tabular}{|c|c|c|c|c|c|c|c|}
\hline \multirow{2}{*}{ Gastrin Level } & & & & & & \multicolumn{2}{|c|}{ Serum Creatinine $(\mathrm{mg} / 100 \mathrm{ml})$} \\
\hline & & & & & & $<3$ & $>3$ \\
\hline $\begin{array}{l}<120 \mathrm{pg} / \mathrm{ml} \\
>120 \mathrm{pg} / \mathrm{ml}\end{array}$ & $\therefore$ & $\therefore$ & $\therefore$ & $\therefore$ & $\therefore$ & $\begin{array}{r}54 \\
7\end{array}$ & $\begin{array}{l}15 \\
13\end{array}$ \\
\hline
\end{tabular}

$X^{2}=13.46 ; P<0.001$.

the degree of impairment of renal function and the raised level of serum gastrin $\left(\chi^{2}=13.46 ; P<0.001\right)$.

Basal gastric acid secretion was estimated in 14 out of 28 patients with a serum creatinine of $3 \mathrm{mg} / 100 \mathrm{ml}$ or over. Acid output ranged from 0 to $8.6 \mathrm{mEq}$ per hour and there was no correlation between basal serum gastrin and basal acid output $(r=0.007 ; P>0 \cdot 1)$.

The serum calcium levels were all within the normal range, as those patients with severely impaired renal function were on oral phosphate-binding agents. There was no correlation between serum gastrin and calcium levels in these patients.

\section{DIALYSIS PATIENTS}

Serum gastrin levels before and after haemodialysis are shown in Table IV. In all but one of these patients the gastrin levels fell over the period of dialysis, but the differences were not significant for the group as a whole $(P=0 \cdot 30)$.

\section{DISCUSSION}

This study shows that basal serum gastrin levels are significantly higher in patients with severe renal impairment than in those with mild impairment or normal renal function. This rise is independent of the type of renal disease present and reflects only the degree of renal dysfunction.
TABLE IV-Serum Gastrin Levels before and after Haemodialysis in Chronic Renal Failure

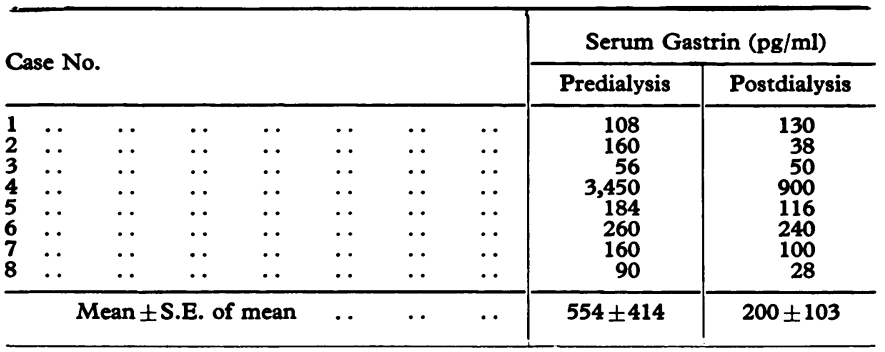

$t=1 \cdot 1427 ; \mathrm{P}=0 \cdot 30$.

It is generally agreed that the liver is not the major site of gastrin degradation or excretion (Gillespie and Grossman, 1962; McGuigan et al., 1970) and so alternative sites have been sought. Sequestration of significant amounts of intravenously administered radio-labelled gastrin in the renal cortex has implicated a renal role in gastrin degradation (Jaffe and Newton, 1969), yet the only report of gastrin levels in chronic renal failure has shown normal values in five patients and no difference after haemodialysis (Reeder and Thompson, 1971). The present results in a larger group of patients do support an important role for the kidney in gastrin metabolism, in that gastrin levels are raised in severe renal impairment. The results also indicate that gastrin does not pass the dialysis membrane in appreciable amounts.

Further corroborative evidence for a renal role in gastrin metabolism is given by preliminary studies of serum gastrin levels after renal transplantation. Three patients studied before and after renal transplantation have shown a return of raised gastrin levels to the normal range.

Other possible explanations of high gastrin levels in chronic renal failure include overproduction, which seems improbable, or increased release associated with achlorhydria. The absence of correlation between acid secretion and serum gastrin, however, indicates that hypergastrinaemia is not due to an associated gastritis and achlorhydria (Korman et al., 1971) and also suggests that the hypergastrinaemia is not associated with an increased acid output.

Further study of these patients, in particular the relation between serum gastrin, gastric acid secretion, and the histological status of the gastric mucosa, will shed some light on the role of the kidney in gastrin metabolism.

The expert technical assistance of Miss Claire Soveny is greatly appreciated. Dr. Priscilla Kincaid-Smith kindly allowed patients under her care to be studied, and Dr. C. W. Baird performed the serum creatinine, urea, and calcium estimations. M.G.K. and J.H. acknowledge the support of the National Health and Medical Research Council of Australia, and M.C.L. the support of the Wellcome Foundation.

Requests for reprints should be addressed to Dr. M. G. Korman, Monash University Department of Medicine, Prince Henry's Hospital, St. Kilda Road, Melbourne, Victoria, 3004, Australia.

\section{References}

Clendinnen, B. G., Davidson, W. D., Lemmi, C. A. E., Jackson, B. M., and Thompson, J. C. (1970). Gastroenterology, 58, 935.

Gillespie, I. E., and Grossman, M. I. (1962). Gastroenterology, 43, 189.

Hansky, J., and Cain, M. D. (1969). Lancet, 2, 1388.

Hansky, J., Soveny, C., and Korman, M. G. (1971). Gastroenterology, 61,

Jaffe, B. M., and Newton, W. T. (1969). Surgical Forum, 20, 312.

Jaffe, B. M., and Newton, W. T. (1969). Surgical
Kay, A. W. (1953). British Medical fournal, 2, 77.

Korman, M. G., Strickland, R. G., and Hansky, J. (1971). British Medical Fournal, 2, 16.

McGuigan, J. E., Jaffe, B. M., and Newton, W. T. (1970). Gastroenterology, $59,499$.

Newton, W. T., and Jaffe, B. M. (1971). Surgery, 69, 34.

Reeder, D. D., and Thompson, J. C. (1971). Gastroenterology, 60, 795.

Snedecor, G. W., and Cochran, W. G. (1968). Statistical Methods, 6th edn. Ames, Iowa State University Press. 